\title{
膀胱癌に対する動注治療の効果の予測因子の検討
}

一ATP -法による抗癌剤感受性試験の有用性について一

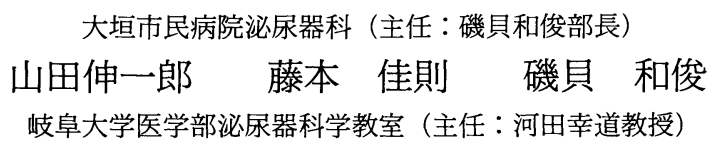

出口 隆 根笹 信一 川本 正吾 西田 泰幸

玉木 正義 江原 英俊 高橋 義人 岡野 学

竹内 敏視 河田 幸道

岐阜大学医学部第一病理学教室（主任：森 秀樹教授)

田中卓二

\section{A STUDY ON PREDICTING FACTORS OF THE EFFECT OF INTRA-ARTERIAL INFUSION CHEMOTHERAPY IN PATIENTS WITH BLADDER CANCERS:}

The Usefulness of In-Vitro Chemisensitivity Test Measuring Intracellular ATP Contents (ATP Assay)

Shin-ichiro Yamada, Yoshinori Fujimoto and Kazutoshi Isogai

Department of Urology, Ogaki Municipal Hospital

(Chief: Dr. K. Isogai)

Takashi Deguchi, Shinichi Nezasa, Shogo Kawamoto, Yasuyuki Nishida, Masayoshi Tamaki, Hidetoshi Ehara, Yoshito Takahashi, Manabu Okano,

Toshimi Takeuchi and Yukimichi Kawada

Department of Urology, Gifu University School of Medicine

(Chief: Prof. Y. Kawada)

Takuji Tanaka

First Department of Pathology, Gifu University School of Medicine

(Chief: Prof. H. Mori)

We studied a relationship between in vitro sensitivity of the tumors to anti-cancerous drugs and histopathological effectiveness of an intra-arterial infusion chemotherapy in 15 patients with bladder cancers. The in vitro sensitivity test was performed by measuring intra-cellular ATP contents (ATP assay). The intra-arterial chemotherapy were performed by injecting methotrexate (MTX), adriamycin (ADM) and eisplatin (CDDP) from the internal iliac artery. When the intra-cellular ATP contents of the tumor cells treated with an anti-cancerous drug decreased to less than $50 \%$ of the untreated tumor cells, the tumor was evaluated as sensitive to the drug. The effectiveness of the chemotherapy were histipathologically evaluated by a pathologist according to the response criteria for bladder cancer treatment. When the histopathological responses of higher than grade 2 were observed in the tumor, the chemotherapy was evaluated as effective. In 8 of 9 tumors sensitive to ADM, chemotherapy were effective histopathologically and in all 6 tumors resistant to $\mathrm{ADM}$, histopathological response of the chemotherapies were poor. The overall coincidence ratio between sensitivity to ADM and the histopathological effectiveness of the chemotherapy was $93 \%$, showing statistically significant correlation. In 7 of 12 tumors 
sensitive to CDDP, the chemotherapies were effective and in 2 of 3 tumors resistant to CDDP, the chemotherapies were ineffective. Although the overall coincidence ratio between the sensitivities to CDDP and chemotherapeutic effectiveness was $60 \%$, there was no significant correlation between them. In 7 of 8 tumors sensitive to both of ADM and CDDP, the chemotherapies were effective and in 6 of 7 tumors resistant to at least one of them, the chemotherapies were ineffective. The chemotherapies were significantly more effective on the tumors sensitie to ADM and CDDP than on those resistant to at least one of them. Therefore, the ATP assay to assess the in vitro chemosensitivity of the tumor would be a potential tool to predict the chemotherapeutic effectiveness in bladder cancers.

Key words: ATP assay, bladder cancers, intra-arterial infusion chemotherapy

\begin{abstract}
要旨：進行膀朕癌15例において動注化学療法前に施行した in vitro 抗癌剤感受性と動注化学療法の組織 学的効果との関係を検討した。抗癌㓮感受性試験は細胞内 ATP 量を指標としたATP 法により行い, 動 注化学療法は内腸骨動脈より methotrexate(MTX), adriamycin (ADM), cisplatin(CDDP)の one-shot 動注にて行った。抗癌剤で処理した腫瘍の細胞内 ATP 量が抗癌剤未処理の腫瘍の細胞内 ATP 量の $50 \%$ 以下であった場合を感受性有りとし, 動注化学療法後の組織学的効果の判定は, 膀胱癌の組織学的 治療効果判定基準で grade 2 以上の変化を認めたものを有効とした. ADM に感受性のある 9 例中 8 例で 化学療法が組織学的に有効であり, ADM に耐性である 6 例すべてで化学療法が無効であった. ADMに 対する感受性と組織学的効果との一致率は $93 \%$ であった. CDDP に感受性のある 12 例中 7 例で化学療法 は有効であり, CDDP に耐性である 3 例中 2 例で化学療法が無効であった. CDDP に対する感受性と組 織学的効果との一致率は $60 \%$ であった. ADM と CDDP 2 凨に感受性のある 8 例中 7 例で化学療法が有 効であり, 少なくとも 1 剤に耐性である 7 例中 6 例で化学療法が無効であった. 両剤に感受性のある腫 瘍は少なくとも 1 洬に耐性を示す腫瘍に比較して有意に良好な反応を示した．以上より今回の ATP 法 による感受性試験は化学療法の効果の予測に有用であることが示された.

キーワード : ATP 法, 膀胱癌, 動注化学療法
\end{abstract}

\section{緒 言}

われわれは，尿路性器腫瘍に対して細胞内 ATP 量 を指標とした in vitro 抗癌剛感受性試験（以下 ATP 法）を行い，各種腫瘍により抗癌剤に対する感受性に 差異のあることと，同種腫瘍においても各々の症例に より感受性が異なることを報告してきだ1).今回われ われは膀腅腫場において ATP 法による in vitroでの 抗癌剤感受性と, 動注化学療法の組織学的効果を比較 し, in vitro での抗癌剤感受性試験が化学療法の治療 効果の予測に役立つかどうかについて検討した.

\section{対象および方法}

(1) 対象

内視鏡下組織生検で組織学的に移行上皮癌と診断さ れ, 超音波検査, CT で深達度が T2以上の進行癌と判 定された膀胱腫瘍15例を対象とした。

(2) 抗癌剂感受性試験

ATP 法は前報1)でも述べたごとく, 生検時得られた 腫腸組織をハサミで細切後, 酵素処理で single cell に
し，15\%牛胎児血清を加えた DM-160培地内に浮遊さ せ, 24-well に各 well $10^{4} \sim 10^{5}$ 個になるように分注し た。抗癌剤を各濃度加え $37^{\circ} \mathrm{C}, 5 \% \mathrm{CO}_{2}$ の条件下で 72 時 間培養後, bioluminescence 法で細胞内 ATP 量を測 定した。使用した抗癌剤は methotrexate（以下 MTX), adriamycin (以下 ADM), cisplatin (以下 CDDP) で，臨床上通常使用する量での血中ピーク濃 度, MTX $1.0 \mu \mathrm{g} / \mathrm{ml}, \mathrm{ADM} 0.4 \mu \mathrm{g} / \mathrm{ml}, \mathrm{CDDP} 2.0 \mu \mathrm{g} /$ $\mathrm{ml}$ で処理した際の細胞内 ATP 量が抗癌剂非添加の コントロール細胞の $50 \%$ 以下に抑制された場合を感受 性ありとした。

\section{（3）動注化学療法}

動注化学療法 ${ }^{2)}$ は Seldinger 法に従ってカテーテル 先端を内腸骨動脈より腫瘍支配動脈に置き，原則とし $\tau \operatorname{MTX} 30 \mathrm{mg} / \mathrm{m}^{2}$, ADM $30 \mathrm{mg} / \mathrm{m}^{2}$, CDDP $70 \mathrm{mg} /$ $\mathrm{m}^{2}$ を one-shot で注入した. 治療回数は全例 1 回とし た.

（4）組織学的効果判定 
動注化学療法後 3 ないし 4 週間後に膀胱全摘出術あ るいは TURにより得られた病理標本について, 動注 治療による組織学的効果を判定した．判定は感受性成 績および臨床効果を全く関知しない病理診断医が，膀 胱癌の組織学的治療効果判定基準 ${ }^{3)}$ に従って行った。

（5）解析

組織学的効果と年齢, 性別, 腫瘍の大きさ，腫瘍の 組織学的異型度 (grade), 腫瘍の深達度 (stage), ADM の投与量, CDDP の投与量, MTX の投与量, ADM に 対する腫瘍の感受性, CDDP に対する腫瘍の感受性の 各因子との相関を Spearman の順位相関係数（rs）と その有意確率 ( $\mathrm{p}$ 值) で検討した。 また in vitro 抗癌剤 感受性と組織学的効果との関係を Fisher の直接確率 計算法を用いて検討した。

\section{結 果}

（1）症例の背景因子，in vitro 抗癌剤感受性および 組織学的効果

Table 1 に全症例の一覧を示した. 15例中男14例女 1 例であり, 年齢は55歳から 83 歳, 平均70歳であった。 移行上皮癌の異型度では grade 1 が 3 例, grade 2 が 8 例, grade 3 が 4 例であった. 深達度は, T2が 9 例, T3 が 5 例，T4が 1 例であった. ADM の投与量は最少 20 $\mathrm{mg}$ から最大 $50 \mathrm{mg}$ で平均 $36.3 \mathrm{mg}$ であった. CDDP の 投与量は最少 $50 \mathrm{mg}$ から最大 $140 \mathrm{mg}$ で平均 $76 \mathrm{mg}$ で
あった. MTX の投与量は最少 0 から最大 $50 \mathrm{mg}$ で平 均 $39 \mathrm{mg}$ であった。これら 3 剂の投与量が原則からか なりはずれた症例があるが，これは各症例の主治医が 患者の状態を考慮し，動注の効果をより高めようと判 断した結果であると思われる。そうした投与量の差の 治療効果への影響も統計学的に検討した。ADMによ る細胞内 ATP 量の抑制率は 0 から $94 \%$ であり平均 48\%であった. $50 \%$ 以上の抑制率を示し ADM に対し 感受性ありと判定したのは 9 例 $60 \%$ であった。CDDP による抑制率は 0 から $99 \%$ であり平均 $64 \%$ であった。 同様に CDDP に対し感受性ありと判定したのは11例 73\%であった。

動注化学療法前後の標本の検討の結果, grade 1a が 1 例， $1 \mathrm{~b}$ が 6 例， 2 が 4 例， 3 が 4 例であった。

（2）各因子と組織学的効果との相関および in vitro 抗癌剤感受性と組織学的効果との関係

組織学的効果と年齢, 性別, 腫瘍の大きさ, 腫瘍の 組織学的異型度 (grade), 腫場の深達度 (stage), ADM の投与量, CDDP の投与量, MTX の投与量, ADM に 対する腫瘍の感受性, CDDP に対する腫瘍の感受性の 各因子との相関を Spearman の順位相関係数（rs）と その有意確率 ( $\mathrm{p}$ 值)で検討したところ，そのうち組織 学的効果と有意の相関を認めたものは，ADM に対す る感受性 ( $\mathrm{rs}=0.6760, \mathrm{p}=0.006)$ (Fig. 1) と, CDDP

Table 1 Patients list

\begin{tabular}{c|c|c|c|c|c|c|c|c|c|c|c}
\hline & 年齢 & 性 & ADM 感受性 & CDDP 感受性 & ADM 量 & CDDP 量 & MTX 量 & T & Grade & 大きさ & 病理効果 \\
\hline 1 & 70 & $\mathrm{M}$ & 3 & 62 & 30 & 50 & 50 & 4 & 2 & $50 \times 30$ & $1 \mathrm{~b}$ \\
\hline 2 & 71 & $\mathrm{M}$ & 80 & 55 & 30 & 70 & 50 & 2 & 2 & $20 \times 15$ & 3 \\
\hline 3 & 55 & $\mathrm{M}$ & 94 & 74 & 30 & 70 & 0 & 3 & 2 & $40 \times 20$ & 3 \\
\hline 4 & 65 & $\mathrm{M}$ & 50 & 55 & 50 & 100 & 50 & 3 & 2 & $40 \times 15$ & 2 \\
\hline 5 & 77 & $\mathrm{~F}$ & 60 & 62 & 30 & 140 & 50 & 2 & 2 & $25 \times 15$ & 3 \\
\hline 6 & 77 & $\mathrm{M}$ & 39 & 98 & 30 & 50 & 50 & 2 & 1 & $30 \times 15$ & $1 \mathrm{a}$ \\
\hline 7 & 71 & $\mathrm{M}$ & 82 & 61 & 45 & 140 & 45 & 2 & 3 & $40 \times 30$ & 2 \\
\hline 8 & 77 & $\mathrm{M}$ & 15 & 99 & 20 & 50 & 50 & 2 & 1 & $40 \times 20$ & $1 \mathrm{~b}$ \\
\hline 9 & 68 & $\mathrm{M}$ & 27 & 91 & 20 & 75 & 0 & 2 & 1 & $25 \times 20$ & $1 \mathrm{~b}$ \\
\hline 10 & 71 & $\mathrm{M}$ & 0 & 45 & 30 & 70 & 30 & 2 & 3 & $35 \times 15$ & $1 \mathrm{~b}$ \\
\hline 11 & 59 & $\mathrm{M}$ & 52 & 67 & 50 & 100 & 50 & 2 & 2 & $30 \times 25$ & 3 \\
\hline 12 & 75 & $\mathrm{M}$ & 0 & 0 & 50 & 50 & 30 & 3 & 2 & $40 \times 30$ & $1 \mathrm{~b}$ \\
\hline 13 & 56 & $\mathrm{M}$ & 79 & 76 & 50 & 50 & 50 & 3 & 3 & $40 \times 30$ & $1 \mathrm{~b}$ \\
\hline 14 & 83 & $\mathrm{M}$ & 51 & 68 & 50 & 50 & 50 & 3 & 3 & $30 \times 30$ & 2 \\
\hline 15 & 77 & $\mathrm{M}$ & 83 & 48 & 30 & 75 & 30 & 2 & 2 & $20 \times 15$ & 2 \\
\hline
\end{tabular}


Fig. 1 Correlation between sensitivity to ADM and histological effect

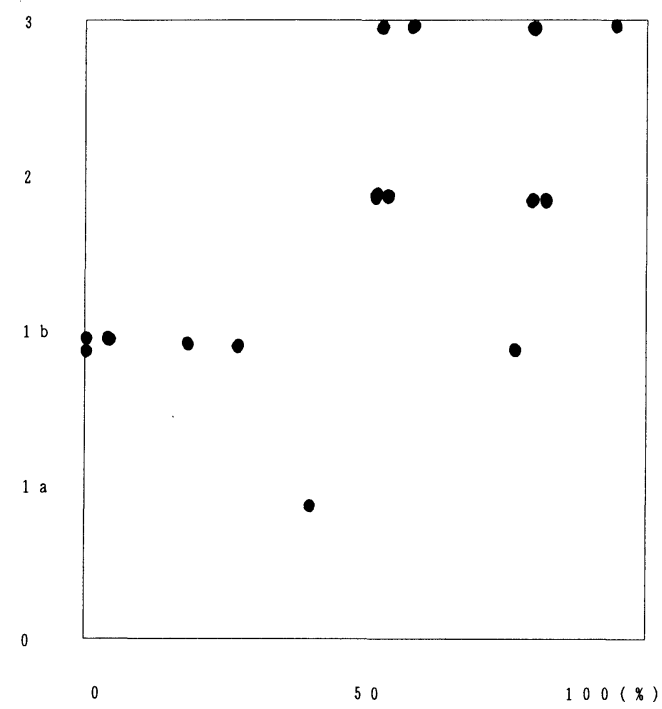

Fig. 2 Correlation between dose of CDDP and histological effect

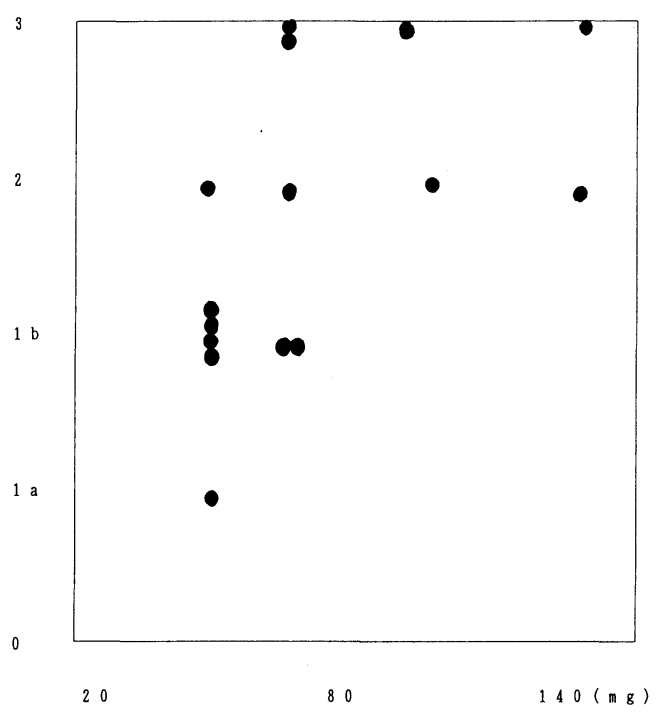

の投与量 ( $\mathrm{rs}=0.6276, \mathrm{p}=0.012)$ であった (Fig. 2). ADM に対する感受性と組織学的効果についてみる と (Table 2), ADM に感受性を認めた 9 例のうち組 織学的治療効果判定基準で grade 3 が 4 例, grade 2 が 2 例, grade $1 \mathrm{~b}$ が 4 例, grade $1 \mathrm{a}$ が 1 例であった。一 方 ADM に耐性であった 6 例では, grade $1 \mathrm{~b}$ が 5 例, grade $1 \mathrm{a}$ が 1 例であった. 化学療法後 viable cell が1/
Table 2 Correlation between sensitivityto ADM and pathological effect

\begin{tabular}{c|c|c|c|c|c|c}
\hline \multirow{2}{*}{ Sensitivity } & \multicolumn{5}{|c|}{ Pathological effect } & \multirow{2}{*}{ Total } \\
\cline { 2 - 7 } & 0 & $1 \mathrm{a}$ & $1 \mathrm{~b}$ & 2 & 3 & \\
\hline+ & & & 1 & 4 & 4 & 9 \\
- & & 1 & 5 & & & 6 \\
\hline & & 1 & 6 & 4 & 4 & 15 \\
\hline
\end{tabular}

Table 3 Correlation between sensitivityto CDDP and pathological effect

\begin{tabular}{c|c|c|c|c|c|c}
\hline \multirow{2}{*}{ Sensitivity } & \multicolumn{5}{|c|}{ Pathological effect } & \multirow{2}{*}{ Total } \\
\cline { 2 - 7 } & 0 & $1 \mathrm{a}$ & $1 \mathrm{~b}$ & 2 & 3 & \\
\hline+ & & 1 & 4 & 3 & 4 & 12 \\
- & & & 2 & 1 & & 3 \\
\hline & & 1 & 6 & 4 & 4 & 15 \\
\hline
\end{tabular}

Table 4 Correlation between sensitivity to ADM and CDDP and pathological effect

\begin{tabular}{c|c|c|c|c|c|c|c}
\hline \multicolumn{2}{c|}{ Sensitivity } & \multicolumn{5}{|c|}{ Pathological effect } & \multirow{2}{*}{ Total } \\
\cline { 1 - 6 } ADM & CDDP & 0 & $1 \mathrm{a}$ & $1 \mathrm{~b}$ & 2 & 3 & \\
\hline+ & + & & & 1 & 3 & 4 & 8 \\
- & - & & & & 1 & & 1 \\
- & + & & 1 & 3 & & & 4 \\
- & - & & & 2 & & & 2 \\
\hline & & & 1 & 6 & 4 & 4 & 15 \\
\hline
\end{tabular}

3 以下となった grade 2 以上を組織学的に化学療法が 有効とした場合には，ADMに対する感受性例におけ る有効例は 9 例中 8 例 (89\%), 耐性例における有効例 は 6 例中 1 例もなく, Fisher の直接確立計算法で有効 率に関して両群間に有意差が認められた（p= 0.0014).全体としては15例中14例 $93 \%$ にいて感受性 の結果と組織学的効果が一致した。CDDPに対する感 受性と組織学的効果についてみると (Table 3), 同様 に grade 2 以上を化学療法が有効とした場合には, CDDP に対する感受性例における有効率は $58 \%$, 而性 例における有効率は $33 \%$ ごこの間に有意差を認めな かった. 全体としての組織学的効果と感受性の一致率 は9/15, 60\%であった. ADM, CDDP 両剤に対する感 受性の結果と組織学的効果との関係をみると（Table 4)， 2 郕ともに感受性を認めた 8 例のうち 7 例 $88 \%$ は

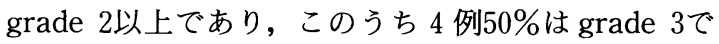
あった.また, 2 剤のうち少なくとも 1 剤に耐性であっ 
た 7 例のうち 6 例 $86 \%$ までが grade $1 \mathrm{~b}$ 以下であり, 1 例 (14\%) のみが grade 2であった. ADM おょび CDDP 2 剤に対してともに感受性を示す腫瘍は，少な くとも 1 剤に耐性を示す腫瘍に比し, 推計学的に有意 の差で $(\mathrm{p}=0.0101)$ 化学療法に対して組織学的に優れ た効果を示した。

また, ADM に対する感受性の有無と CDDP の投与 量との独立性をみるために以下の検討を行った。 $\mathrm{CDDP} 70 \mathrm{mg}$ 以上投与群と $70 \mathrm{mg}$ 未満投与群との間で 組織学的効果との関連性を Fisher の直接確立計算法 で検討したところ, CDDP $70 \mathrm{mg}$ 以上投与群における 効果は 9 例中 7 例 $(78 \%)$ と CDDP $70 \mathrm{mg}$ 未満投与群 の 6 例中 1 例（17\%）にくらべ有意に高かったため $(\mathrm{p}=0.035), \mathrm{ADM}$ 感受性群, 而性群のそれぞれにおけ る CDDP $70 \mathrm{mg}$ 以上投与例と70未満投与例の頻度を 検討したがその頻度に有意差は認められず（ $\mathrm{p}=$ 0.1189), 両群間に CDDP 投与量に関して偏りはない と判断した.したがって, ADM に対する感受性の有無 と CDDP の投与量とは独立して評価を検討すること が可能であると考えられた。

\section{考 察}

膀胱癌, とくに筋層を越えた浸潤を示す進行膀胱癌 に対する治療効果は, 最近の化学療法の進歩に伴い向 上してきた. Sternberg ら゙)にって紹介された， MTX, ADM, Vinblastine, CDDP の併用療法 (MVAC) は最近では膀胱癌の adjuvant chemotherepy として最も有効な治療法のひとつとされている 注療法は腫瘍支配動脈に選択的に高濃度の薬剤を注入 できるため，抗癌剤の抗腫瘍効果の向上のみならず全 身投与に比べその副作用が少ないなどの点より, 癌治 療の中核的治療となってきている．膀胱癌に対する動 注療法は, 腫瘍組織ばかりでなく所属りンパ節に高濃 度の抗癌剂を暴露でき ${ }^{6)}$, さらに静注治療と同様の全 身療法としての効果が期待でき, 有効な neoadjuvant 治療とされている7). 当教室では, 進行膀羘癌に対して 腫瘍の down stage, 膀胱温存, 予後の改善を目的とし て, 手術前に MTX, ADM, CDDP の動注を行ってき た。しかし症例によっては内腸骨動脈より効率よく薬 剂を投与出来たにも拘らず，十分な臨床効果が得られ ない場合も少なくない. 化学療法前にその効果の予測 が可能であれば臨床上意義のあることと思われる. そ こで, 治療前に腫瘍の in vitroにおける抗癌剤に対す る感受性を ATP 法帛を用いて測定し，その結果から動 注化学療法の効果の予測が可能かどうかについて検討
した. 今回の検討では, ATP 法の化学療法の効果の予 測における有用性を検討することを目的としたため, 動注化学療法の薬剤および投与方法は統一し, ATP 法の結果による薬剤の変更は行わなかった. 化学療法 の効果は主に画像診断により判定されるが, 化学療法 後の腫瘍部の浮腫, 出血, 肉芽形成などにより過小評 価される可能性があり, 今回の検討では臨床経過およ び感受性の結果を関知しない病理診断医に組織学的検 討を依頼し,客観的な化学療法の効果の判定を行った. 前報1でも報告したが，MTX は濃度・時間依存性薬剤 であり, ATP 法による検討では過小評価される可能 性があるため今回の検討からは除外した。

$\mathrm{ADM}$ に対する感受性と化学療法が奏功したと考え られる grade 2 以上の組織学的効果との間に有意の相

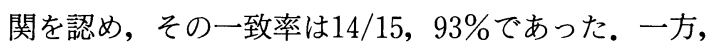
CDDP に対する感受性と組織学的効果との間には有 意の相関は認めなかったものの全体での一致率は9/ 15，60\%であった. ADM と CDDP とに感受性を示す 症例と 1 羭以上に而性の症例とでは, 化学療法の組織 学的効果の間に有意の差が認められた。また, Spearmanの順位相関係数とその有意確率での検討で $\mathrm{ADM}$ に対する感受性と CDDP の投与量が動注の組 織学的効果と有意の相関を認めたが, この両者間には 有意の関連を認めず, Fisher の直接確立計算法では ADM に対する感受性のみが組織学的効果に有意の相 関を示したことより，今回の検討では ADM に対する 感受性が動注療法の効果と最も関連性が強いと考えら れた。

また, 膀胱腫瘍の grade と組織学的効果とは, Spearman の順位相関係数 $\mathrm{rs}=0.2195$ とその有意確 率 $\mathrm{p}=0.432$, stage と組織学的効果とは $\mathrm{rs}=-$ $0.1064, \mathrm{p}=0.706$ と有意な相関を認めず，今回の検討 においては動注の効果予測因子とはならなかった。

以上より治療前にATP法による感受性試験を行 い, その感受性結果より動注化学療法の効果の予測が 可能であることが示された。

しかしながら今回の ATP 法による検討では, 化学 療法の効果は ADM の感受性をよく反映したが, CDDP の感受性との間には有意の相関は認められず, また同時に用いた MTXについての感受性の評価が 不能であった。感受性試験における薬剤の濃度, 今回 有効と判定するのにコントロールに対する抑制率を $50 \%$ としが，より臨床効果に反映するための各薬剤 についての cut-off point の設定, 時間依存性薬剤の評 
価法などいくつかの課題を残している．これらを解決 することにより, 膀胱腫瘍における in vitro 抗癌剤感 受性試験は化学療法の効果の予測のみならず，無効な 薬剤の排除および有効薬剤の選択に有用となり，ょり 副作用の少ない効果的な化学療法が可能となるものと 思われる. 今後さらに症例を増やし, 臨床効果, 組織 学的効果からより実際的な ATP 法を確立して行きた い.

\section{文 献}

1）山田伸一郎, 出口 隆, 根笹信一, 玉木正義, 江厚 英俊, 岡野 学, 河田幸道: 細胞内 ATP 量を指標 とした尿路性器腫瘍の抗癌剤感受性試験の検討. 日泌尿会誌，83，2022-2028，1992.

2) Ogata, J., Migita, N. and Nakamura, T. : Treatment of carcinoma of the bladder by infusion of the anticanter agent (mitomycin $\mathrm{C}$ ) via the internal iliacartery. J. Urol., 110, 667-670, 1973.

3) 日本泌尿器科学会, 日本病理学合編：泌尿器科癌 の治療効果判定基準. 日泌尿会誌，83，447-472, 1992.

4) Sternberg, C.N., Yagoda, A., Scher, H.I., Watson, R.C., Ahmed, T., Weiselberg, L.R., Geller, N., Hollander, P.S., Herr, H.W., Sogani, P.C.,
Morse, M.J. and Whitmore, W.F.: Preliminary results of M-VAC (methotrexate, vinblastine, doxorubicin and cisplatin) for transitional cell carcinoma of the urothelium. J. Urol., 133, 403-407, 1985.

5) Scher, H.I., Yagota, A., Herr, H.W., Sternberg, C.N., Bosi, G., Morse, M.J., Sogani, P.C., Watson, R.C., Dershaw D.D., Reuter, V., Geller, N., Hollander, P.S., Vaughan, E.D., Jr., Whitmore, W.F., Jr. and Fair,, W.R.: Neoadjuvant MVAC (methotrexate, vinblastine, doxorubicin and cisplatin) effect on the primary bladder lesion. J. Urol., 139, 470-474, 1988.

6) 加納勝利：膀胱癌の集学的治療. 日泌尿会誌, 76, 1926-1628, 1985.

7）比嘉 功, 早川正道, 宍戸清一郎, 小倉秀章, 謝花 政秀, 小山雄三, 秦野 直, 大沢 炣 : 動注療法の 理論的根拠と臨床効果. 西日泌尿, 52，425-430, 1990.

8) Garewell, H.S., Ahmann, F.R., Schifman, R.B. and Celniker, A.: ATP-ajjay: Ability to distinguish cytostatic from cytocidal anticancer drug effects. J. Natl. Cancer Inst., 77, 1039 $-1054,1986$.

（1994年 1 月24日受付， 6 月16日受理） 